\title{
Theatre Teaches
}

\author{
Bannò, Mariasole ${ }^{\mathrm{a}}$; Albertini, Andrea ${ }^{\mathrm{b}}$; Bendar, Ahlam ${ }^{\mathrm{a}}$; Bodini, Ileana ${ }^{\mathrm{a}}$; Trento, \\ Sandro $^{c}$ and Villa, Valerio ${ }^{a}$ \\ ${ }^{a}$ Department of Industrial and Mechanical Engineering, University of Brescia, Italy, ${ }^{b}$ La \\ Betulla, Theatre Company, Italy, ${ }^{\mathrm{c}}$ Department of Economics and Management; University \\ of Trento, Italy
}

\begin{abstract}
Theatre Teaches is a new experiment carried out at the University of Brescia. The growing importance of transversal competences i.e. those skills that essentially concern attitudes in the workplace and interpersonal relationships such as team work, language and communication skills, gave us the idea to develop an educational innovation to help students bring out these skills. We asked students to wrote a play using topics seen in class and get him to scene. Not to be confused to business theatre, this method is applicable in any framework. The assessment results reveal that students appreciate this method because this work helps them to express theirself better and, in general terms, they could improve their non technical skills. In conclusion, we can say that this experiment has been a success and gave the students the opportunity to show transversal competences. The ability to communicate, to teamworking, to manage conflicts, to speak in public, to problem solving, creativity, imagination, the ability to manage unforeseen situations and tolerate pressure and stress, leadership skills, negotiation skills and the ability to motivate are just few of the emergent competences.
\end{abstract}

Keywords: Learning techniques; theatre, transversal competences; educational innovation, Economic, managerial and engineering education. 


\section{Introduction}

To play is present even in the most primitive social organization, with various aims and in different ways. In Greece, in the fifth century B.C., to play took the form and the glossary that we still use. For the anciest Greeks, if philosophy was the science, then theater was a laboratory activity, to focus on the dilemmas that anguished ancient questioners. This practice is actual, even today. Just think of the tragedy of Antigone, in conflict between respect for the law or his deepest values: does it not correspond to the current need, which many of us meet, to have to address an ethical committee when projects involve the privacy of people?

The authors are well aware that knowledge, skills and ability have to be considered together and integrated when working on teaching design (Krathwohl , 2002). Moreover, Fredricks et al. (2004) and Kahu (2013) say that involvement of the whole person is achieved through an approach that includes intellect, practice and emotion. For example, comic book stories can be useful to break the ice with the most struggling students. As Metraglia et al. (2014) say, comics tell the typical work situations in a funny way, or they help self-recover prerequirements gaps (Baronio et al. 2016). The most advanced instruments tested by Violante et al. (2016) for online learning environments with three-dimensional functions should also be evaluated. Finally, Motyl et al. (2017) underline that providing the expertise, which will be required of future graduates, is an important task.

Now, talking about theatre, what happens if we ask 63 graduates of economics and engineering to process and stage scripts that address the themes of their studies? How is their creativity at stake? What happens to their ability to interact, listen and communicate? What happens to their self-image and self-esteem? As will be illustrated in this paper, this mode, which has been called Theatre Teaches, is different from the more traditional "Teatro d'impresa ${ }^{\circledR}$ " offered to managers of companies.

\section{Methods and Objectives}

In the first phase, but only after the professor carried out the more traditional part of the teaching, we tried to know each other, teacher and students, without the typical firstmeeting-embarrassment, also trying to remove mental oxidations typical of our individual society, such as halfway gestures, voices that can't be heard, etc. (Pfeiffer at al., 2017). To create a group imprinting, a scream of war was chosen to start each lesson, in order to free the tension, create a slogan, a recognizable sign within the same group. "Ut! Ut! Ut!" (Out! Out! Out!) was chosen, which was the motto that the troops of Aroldo II shouted to the Bretons of William the Conqueror during the battle of Hastings. The 63 diaphragms, half boys and half girls, made the walls of the Athenaeum to vibrate, overwhelming us like a 
wave. To liberate the primordial instinct students were asked to move, scream and communicate as monkeys in order to gain awareness of their body, space and voice. Finally, in the most authentic spirit of theatrical improvisation, the students were asked to alternate in small and stage a small performance without preparation choosing among the subjects of the course (Amaral et al., 2017; Senje, 2017). This has resulted in extemporaneous, exhilarating, grotesque and significant situations in which everyone was involved. After this fist liberating phase, the Actor illustrated the characteristics of theatrical techniques, here proposed in Table 1.

Table 1. Techniques of the theatre

\begin{tabular}{|c|c|}
\hline Individual & Group \\
\hline $\begin{array}{l}\text { To enhance expressive and communicative } \\
\text { skills, through the use of body and voice; to } \\
\text { widen the perception of physical and imaginary } \\
\text { space; to develop the imaginary through } \\
\text { improvisation, internalizing the characters and } \\
\text { the stories; to sustain to verbalize feelings and } \\
\text { emotions; to improve self-image and self- } \\
\text { esteem; to discover the infinite possibilities that } \\
\text { body and voice have of expressing themselves, } \\
\text { through control and empowerment; to try to } \\
\text { communicate experiences, emotions, and } \\
\text { moods in an authentic and creative way; to read } \\
\text { a script, developing contents, gestures, rhythms } \\
\text { and vocal emission; to learn how to use } \\
\text { symbols and objects for a staging; to remove } \\
\text { masks and embarrassments by promoting } \\
\text { expressiveness. }\end{array}$ & $\begin{array}{l}\text { To encourage the ability to listen oneself and } \\
\text { within the group, promoting relationships with } \\
\text { others; to learn how to know themselves, their } \\
\text { own limits and resources and those of the } \\
\text { group; to bring out and promote potentialities } \\
\text { and capacity, and putting them in relation to } \\
\text { those of others; to acquire control and } \\
\text { knowledge of space; to develop a } 360^{\circ} \\
\text { perception of the environment in which to } \\
\text { move and how this can change in relation both } \\
\text { to the presence of people in the group and to } \\
\text { their imagination; to analyze people, everyday } \\
\text { and non-daily situations to be represented on } \\
\text { the scene; to characterize characters; to increase } \\
\text { self-confidence and trust with each other; to } \\
\text { help each other through the common goal of the } \\
\text { final representation. }\end{array}$ \\
\hline
\end{tabular}

Source: Our elaboration.

In the second phase the students were allowed to self select into groups of 7 to 10 people and wrote a script, dealing with directing, with the description of the characters, the creation of movements within the stage space, the choice of furnishings and costumes, lights and music. The added value of this theatrical exercise was the writing of an original script by students, as the result of their ideas and fantasy (Pfeifferet al., 2017). The script was then given a more institutional scenic form by the Actor then it has become a real play where the actors and techincians were the same students that wrote the play. All pieces have been performed in one of the most important theatres in the city, under the patronage of the municipality. 


\section{Experimental Activity: Different Point of View}

\subsection{The Actor}

I believe that acting a character in theatre is an expressive way of communicating with features that go beyond all other forms of communication. Acting a script character, treading the boards, is not just a narcissistic exercise to show themselves, but it is, above all, a team effort. Remember your own words and movements, but also pay attention to words of the other characters and, in the same time, also to their change of position on the stage, their scenic times. A mutual help, trying to let words and feelings flow, to achieve the exact viscosity of the entire theatrical mechanism. A narrative mechanism created to tell: body, voice, symbols, acting one of the endless possible realities, one of the infinitive symbolic possibilities. Free from rigidity, from masks, from that arid and binding attitude that thickens during the days and often does not allow us to be ourselves. Fiction must be relegated to the stage, not to everyday life. Theatre requires feelings to be brought to the paroxysm, to their extreme expression, to their ultimate meaning, so that they can become the symbol of a story. Students, after a first dubious and doubtful involvement in the project, have then expressed their enthusiasm. All played on the stage. Nobody wanted to give up. Those who haven't acted, have coordinated the music or helped the others in a thousand other ways: writing the script, getting the props and costumes, choosing the songs. This was also the purpose of this experience. What the students really are have been shown: their contradictions, certainties, hardships, abilities, fears. The play showed life, a crosssection of the infinite kaleidoscope of reality, one of the possible innumerable stories and not just a business case or an economic or engineeristic situation. Fiction, but not untruth, not a lie. Making theater actually makes everything more true and the people more authentic.

\subsection{A student}

(...) we were worried to make a fool of ourselves in front of the other colleagues, those serious, that would have seen us out in the garden making improvisation exercises, trying to act out machine parts too: that's crazy! We forgot that the course wouldn't be like the other ones. (...) By the way, in state of the emotional distress, we just let things get out of hand. We have not decided, we have accepted. (...) "But Prof, how I can do this? I've never done this before!". You'll learn, of course, you'll learn. And what happen when you put the squeeze on someone? He's doing, It's an inherent part of us, called self-preservation. And when everything goes on a roll, you feel like a super human, a hero that beat the villains. So, you discover that you have talent in managing tasks, often last-minute-assigned. And you immediately think about your father that has to deal unforeseen events or to make planning. And you can feel that you learnt how to do this you too. And you are ready to address next difficulties. Theatre Theaches isn't only the theatre that we know. It's public 
speaking, improvisation, open-mindedness, overcoming the awkwardness, bringing us closer together, learning the topics in an alternative way, involving our senses to the topics studied. Making theatre means letting on the line visual memory, associative memory, and why not, sensorial memory too. Our active involvement let us to learn and to remember best. This is the deep meaning of the "Learning Pyramid " (Molenda, 2003). Thinking about the studied topics, all of us felt that we had learnt them in a better way, because they were something we associated to practical examples and experiences that we lived. Lately we talk a lot about "soft skills", but do we know what these are? They aren't something that someone can teach, they are predispositions or elements that we can acquire by experiences. And experiences like theatre can spur us on develop them. These are competences that we aren't able to develop by the teaching we are used to. So, if participating actively to theatre means know best the topics, if it means let us to find our best and it let us to be more ready to enter to the world job, then all of this it's not more a craziness!

\subsection{A team of Students: the Script}

Figures 1 to 8 of this paragraph are neither numbered nor captioned so as not to disturb the reading of the screenplay. (Source: all the photos are of our production)

This play is about Time, its meaning and how it brings changes. The title is: Waves' thoughts. A man's rise or defeat depends on the flowing seconds just like the surface water is ruffled by the waves. The comparison between a businessman thoughts and the voices of two economists of the past lights the endless daily flow of concerns of

the modern businessman. However, the best advice to overcome hardship of life will come from his mother.

(We are on a beach. The beach is done of nothing. The sea and the song of the birds are background sounds. On the left, a man sits on the ground and plays a guitar: "The sound of silence". The guitarist is always on the stage, on a side, sitting downstage, cross-legged, on the ground)

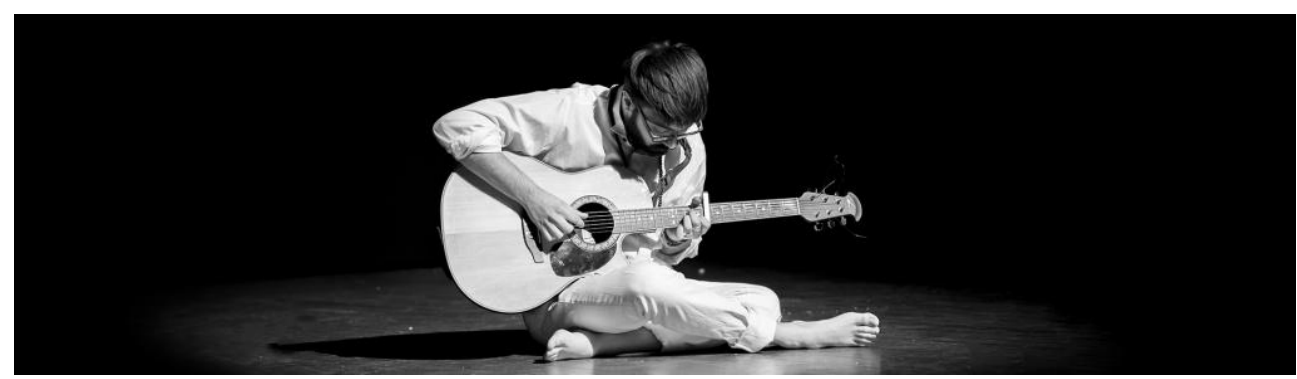

(A barefoot man arrives, wearing pants with cuffs to not soak them.

He sits on the ground, in the sand, and starts talking)

BUSINESSMAN: What have we lost? We lose our creativity or we were not from the beginning? Sometimes I ask myself how are the other me, the one who didn't go the university: better go to work. Or the one who didn't catch the bus that Saturday morning. You want to be a good guy, so you stop at crosswalk to let a woman with Russian eyes to cross the street. She thanks you and comes back home just 4.7 seconds early, so that a brick falls on her head. The Russian-eyed woman is dead now. You wait a minute, and think about how many people have you 
killed without knowing. Maybe none. Maybe one. Maybe one is my good friend. Another sucks. But the "butterfly effect" sucks, and fortunately we don't see it.

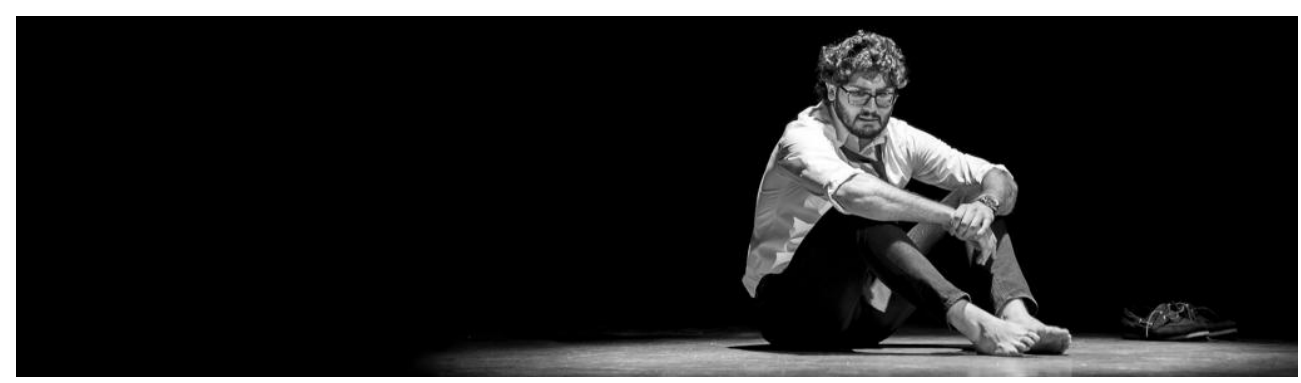

(A man wearing '800 clothes arrives in a ridiculously way. He sits on the ground, next to the businessman)

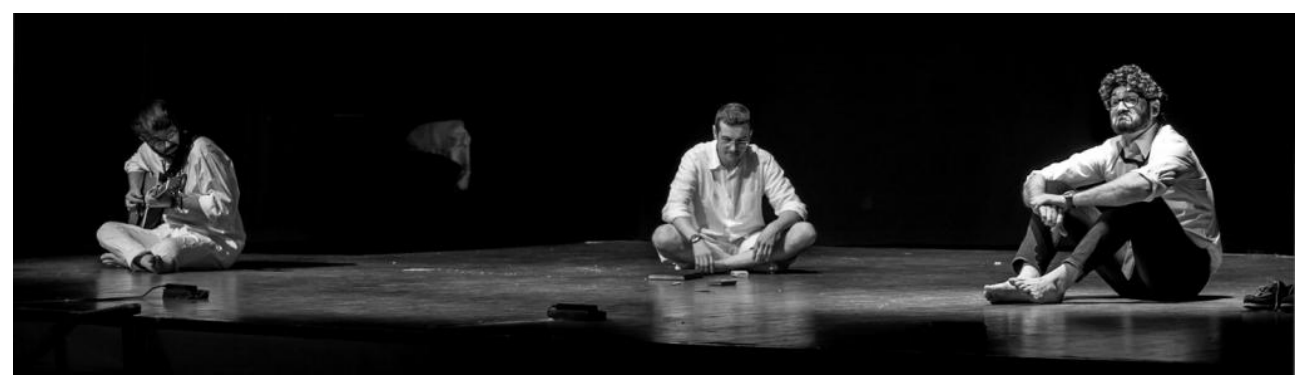

ADAM SMITH: Where are we? || BUSINESSMAN:I don't know. It seems a beach. Who are you? || ADAM SMITH: Adam Smith. || BUSINESSMAN: Ah ah ah, good! And what are you doing here? || ADAM SMITH: I'm, somehow, waiting. Do you want a cigarette? || BUSINESSMAN: No, thanks. I'm not smoking. || ADAM SMITH:

Good boy, smoking is a bad habit.

\section{[...] awkward silence}

BUSINESSMAN: Tomorrow I will have to shut down my business, my firm. It will not be exactly tomorrow, but tomorrow will be the day in which I will have to tell people. For a minute I'd like to be the head of a corporation: you are not required to look in the eyes your 600.000 workers when you're firing them. 21 people work for me. When 21 people work for you, if you don't look them in the eyes you're being rude. I know their name, in some terrible cases I also remember their wife's name, o their parrot. || ADAM SMITH: Never in a month of Sundays! || BUSINESSMAN: Ok! I know you came from the past, but you can talk normally! \| ADAM SMITH: Thank you, you're doing me a favor. You have sympathy. You're nice, don't worry, but I don't mean in that way. You have sympathy, I mean, you are involved with emotions. Stoicism thinks the universe as a big living being, constantly crossed by the living spirit, the "pneuma". The sympathy is the interdependence between all the parts of the universe, where each event is related to every part of the world. || BUSINESSMAN: Wow. Did you copy it? \|

ADAM SMITH: Yes, I did. \|

\section{[...] awkward silence}

ADAM SMITH: And what could you do? Instead of closing, I mean? BUSINESSMAN: To slowly bankrupt, I think.

(A woman enters, slowly, and sits on the ground) 


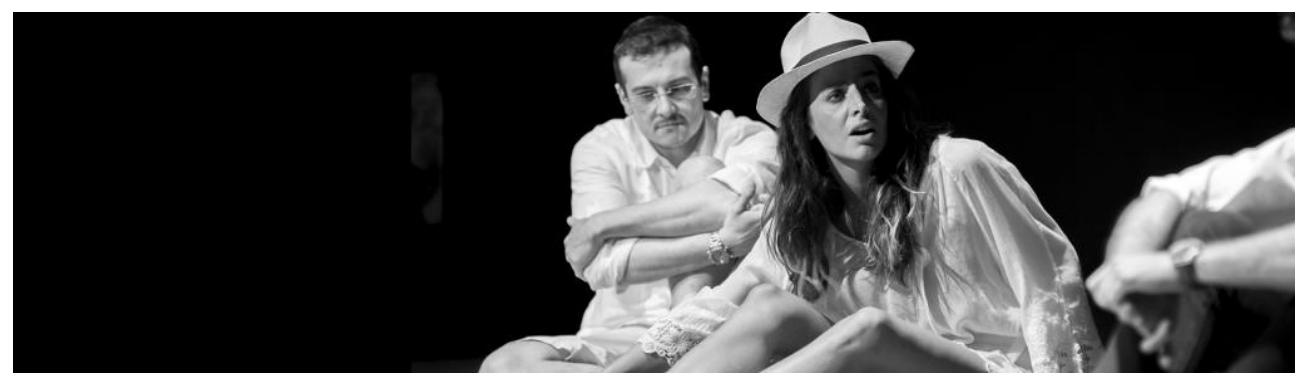

BUSINESSMAN: And who are you? || GEORGESCU: I am Nicholas Georgescu-Roegen - BUSINESSMAN: And why don't you talk Romanian? || GEORGESCU: (Trying to hardly speak Romanian) sarutmana... pentru... masa... || BUSINESSMAN: Give it up. Why are you a woman? || GEORGESCU: Does it make a difference? I will give you an advice: you are too egocentric. Do you think you can decide on people's future? You think you're worth something? You think you can make a difference? Does the control you think you have on others turn you on? Have you ever heard of bio-economy? Physics laws are inevitable, and also economics sciences have to take them into account. Have you ever thought our blood as an endless battlefield of organisms, globules and so on? If this perfectly equilibrated conflict will end our body will not work anymore. Maybe you are not considering the problem from the right point of view. Don't you think you are a pawn in a bigger and inscrutable plan?

A guitar life performance of "the sound of silence" starts. The guitarist is always on the stage, on a side, sitting downstage, cross-legged, on the ground.

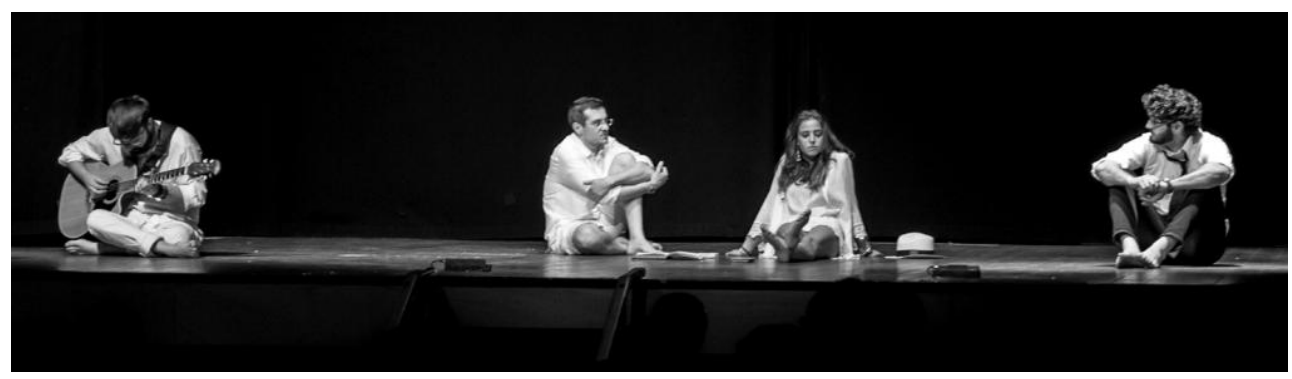

BUSINESSMAN: Just a question. Do you also hear a music? || ADAM SMITH: Of course, it is "The sound of silence". Whoever the musician is, he is undoubtedly poor. But this song is like the sea: you surely cannot complain even if it continues endlessly.

A simply-dressed woman enters, and sits.

BUSINESSMAN: Oh my God, Mum, what are you doing here. Let me be, I'm thinking. || MOTHER: My son, you are disappointing me. I would have been there in the right moment you broke. In the right moment you became blind, and you stopped to look at your men. || BUSINESSMAN: But I know them, one by one. \| MOTHER: No, you know how to count them. You know how to divide, multiply and weight them according to their productivity. Their time is money for you, and their life the added value on you CV. $\|$ BUSINESSMAN:

Mum, how things got so complicated? Why do we feel so lonely in this universe, even if we behave as if someone is always looking at us? Mum, I have calculated the world debt: it is infinite. There is not enough money on this

Earth to repay it. And, what name will we have to write on the check? || MOTHER: The tide's coming in, I have to go. || ADAM SMITH: "Mercy to the guilty is cruelty to the innocent". || GEORGESCU: "It's all an entropy question, after all”. || MOTHER: Wake up, and dig in the future. 
The alarm rings, darkness. The end

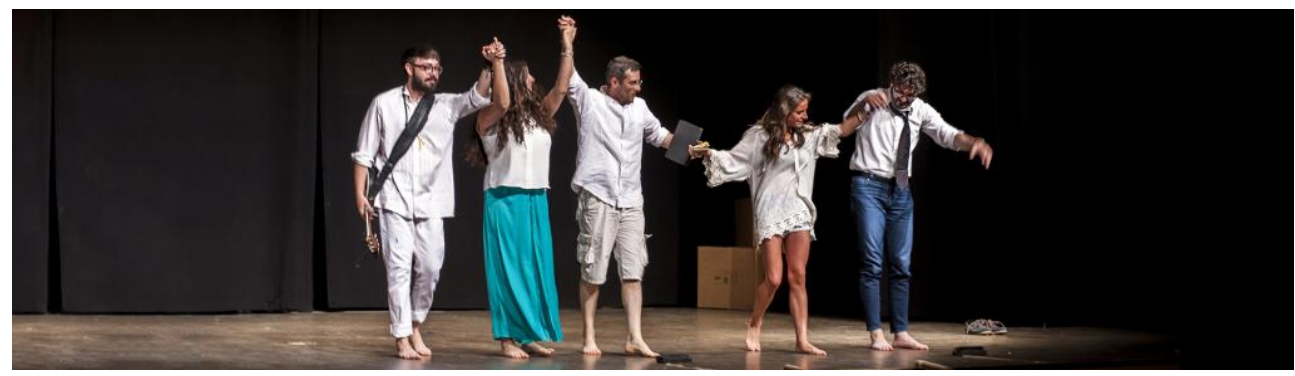

\section{Discussion and Conclusion}

To analyze the effectiveness of this type of teaching, a simple question was put to the students during the written examination, with regard to the reasons why the proposed initiative was more effective than other ones: "What are the positive aspects and what are the negative ones, related to the teaching experience of the course?" A first analysis of responses, carried out by simply identifying keywords, reveals the results in Figure 1.

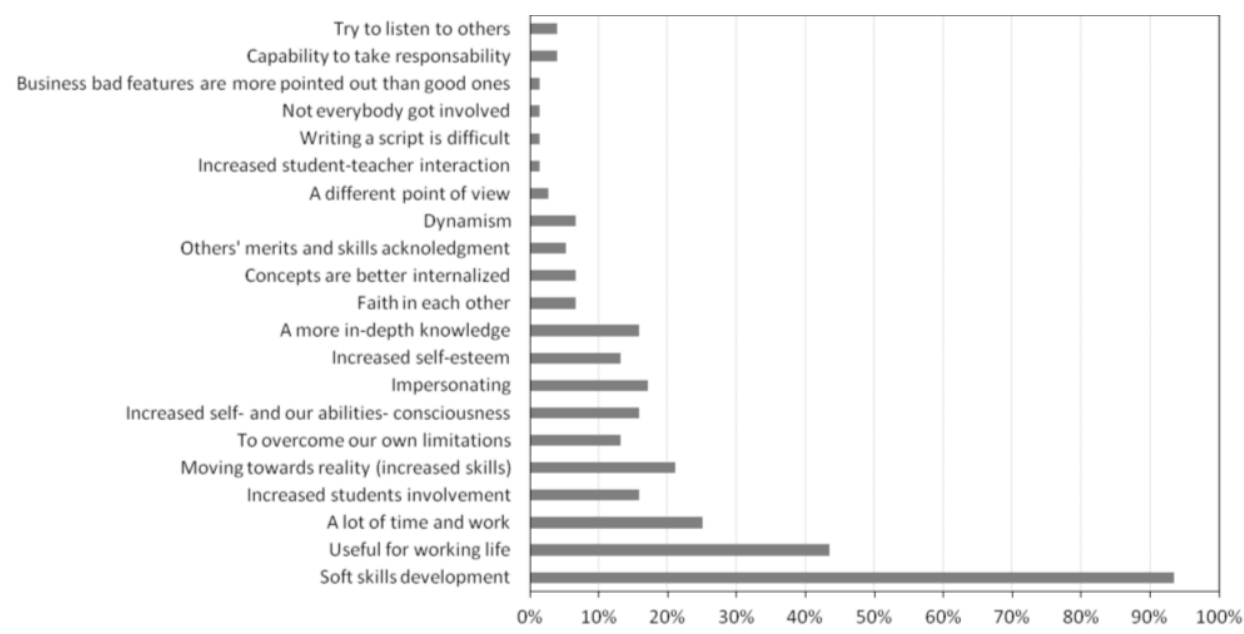

Figure 1: Percentage of answers for every single identified competece Source Our elaboration.

The students recognize the transversal competences, as positive aspects, and divide them in three main categories: relational soft skills (e.g.. communication skills, team-working skills, conflict management skills, public speaking); cognitive soft skills (e.g. problem solving skills, creativity, imagination, the ability to manage unforeseen situations and to tolerate pressure and stress); managerial soft skills (e.g. leadership skills, negotiating skills and the ability to motivate). To better analyze these answers Figure 2 has been computed. 


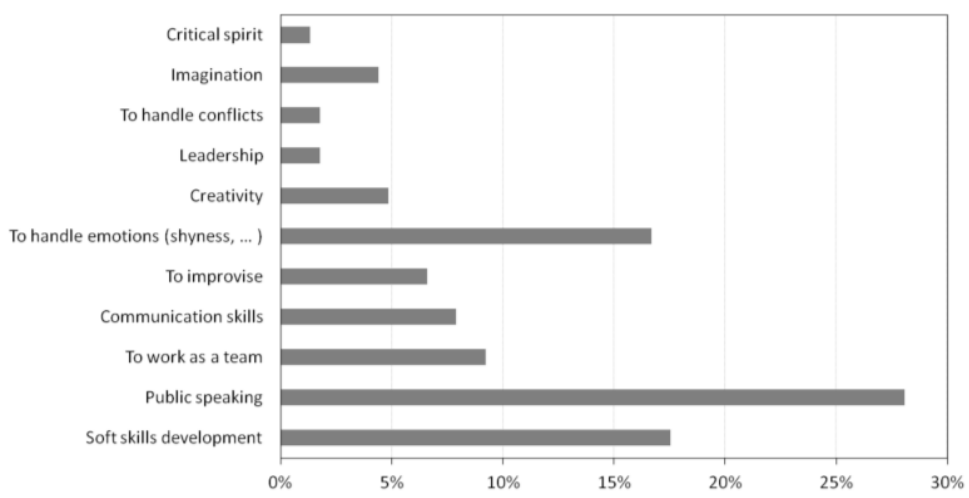

Figure 2: Percentage of answers for every single identified soft skill. Source: Our elaboration.

According to Fredricks et al. (2004) and Kahu (2013), these categories compose the "Student Engagement": emotional engagement, i.e. students' feelings towards teachers, peers, the course and learning; cognitive engagement, i.e. task-specific thinking that a student develops and uses while undertaking in an activity; and behavioral engagement, i.e physical participation in an activity. The result of this experimentindicate that there is a significant potential to improve students' competencies through creativity which is developed using Theatre Teaches.

\section{References}

Amaral, S. V., Montenegro, M., Forte, T., Freitas, F., \& Cruz, M. T. G. D. (2017). Science in Theatre. An Art Project with Researchers. Journal of Creative Communications, 12(1), 13-30.

Baronio, G., Motyl, B., \& Paderno, D. (2016). Technical Drawing Learning Tool Level 2: An interactive self learning tool for teaching manufacturing dimensioning. Computer Applications in Engineering Education, 24(4), 519-528.

Fredricks, J. A., Blumenfeld, P. C., \& Paris, A. H. (2004). School engagement: Potential of the concept, state of the evidence. Review of educational research, 74(1), 59-109.

Krathwohl, D. R. (2002). A revision of Bloom's taxonomy: An overview. Theory into practice, $41: 4)$ pp. 212-218.

Kahu, E. R. (2013). Framing student engagement in higher education. Studies in higher education, 38(5), 758-773.

Metraglia, R., \& Villa, V. (2014). Engineering graphics education: webcomics as a tool to improve weaker students' motivation. Research Journal of Applied Sciences, Engineering and Technology, 7(19), 4106-4114.

Molenda, M. (2003). Cone of experience. Educational technology: An encyclopedia.

Motyl, B., Baronio, G., Uberti, S., Speranza, D., \& Filippi, S. (2017). How will Change the Future Engineers' Skills in the Industry 4.0 Framework? A Questionnaire Survey. Procedia Manufacturing, 11, 1501-1509. 
Pfeiffer, F. M., Bauer, R. E., Borgelt, S., Burgoyne, S., Grant, S., Hunt, H. K. \& Schmidt, D. C. (2017). When Theater Comes to Engineering Design: Oh How Creative They Can Be. Journal of biomechanical engineering, 139(7).

Violante, M. G., \& Vezzetti, E. (2017). Guidelines to design engineering education in the twenty-first century for supporting innovative product development. European Journal of Engineering Education, 42(6), 1344-1364.

Senje, Siri. "Formatting the imagination: A reflection on screenwriting as a creative practice." Journal of Screenwriting8.3 (2017): 267-285. 